\title{
IMPROVEMENT OF PUBLIC GOVERNANCE BY OLOF PALME AND HIS HISTORICAL IDEOLOGICAL HERITAGE (30 YEARS AFTER THE ASSASSINATION OF PALME IN STOCKHOLM)
}

\author{
ARVYDAS GuOGIS ${ }^{1}$, AdOMAS VinCAS RaKŠNYS ${ }^{2}$ \\ Mykolas Romeris University (Lithuania)
}

\begin{abstract}
The essence of the "Swedish socialism" created in the $20^{\text {th }}$ century lies in "democratic functional socialism". During the last 30 years, even after having refused part of its elements, it remains the foundation of the Swedish welfare state, and historically the name of the "Swedish socialism" is mostly related to the famous Swedish and global figure of the smart political powers, social democrat Olof Palme. The article reviews the features of the biography of Olof Palme and his both theoretical and practical activity opting for social justice and by creating a welfare state in Sweden by the means of "democratic functional socialism". Olof Palme was also an advocate of human rights and freedoms, neutrality of small countries, an international mediator, an advocate of nuclear disarmament policy and a severe critic of neo-liberal ideas.

KEY WORDS: Olof Palme, Sweden, social democracy, democratic socialism, functional socialism, welfare state, public governance, peace.
\end{abstract}

JEL CLASSIFICATION: B 14, L 30.

\section{Introduction}

Sweden is a country which in the course of the $20^{\text {th }}$ century not only declared but was also implementing foreign policy of "active neutrality", and inside it was creating the most advanced "welfare state" of the time, which was based on labor movement. The "golden age" of Sweden's welfare state resulted in the governance of the long-term chairman of the labor party of the social democrats and the prime minister Olof Palme, which was terminated by his assassination in February 1986 (1986: Swedish prime minister assassinated). This year marks 30 years since this senseless act which precluded Palme from implementing a number of public sector governance innovations that he initiated, which, as all previous ones, reinforced social justice in the country and remained unrivaled role model in the history of the world, whose example other countries tried to follow. The aim of this article is to analyze the theoretical and practical activities of domestic and foreign policy of Olof Palme with regard to the values by commemorating a 30 years tragic anniversary from his death on that unfortunate 28 February, when he was killed near the cinema as he was walking with his wife Lisbet home after watching a film.

1 Arvydas Guogis - prof. dr. Mykolas Romeris University, Faculty of Politics and Management, Institute of Public Administration, Lithuania. Scientific interest: public administration

E-mail: arvydasg@mruni.eu

2 Adomas Vincas Rakšnys - doctoral student Mykolo Romerio University, Faculty of Politics and Management, Institute of Public Administration, Lithuania. Scientific interest: public administration

E-mail: e_cnv@yahoo.com 


\section{The features of Palme's biography and important political positions}

Olof Palme was born in Stockholm in a well-to-do family on 30 January 1927 (About Olof Palme. Olof Palme International Centre, updated 2016). His father died when he was barely 7 years old. As a child, Olof attended a private school, he was often ill, but he was reading a lot, therefore, he learned several foreign languages soon. Later on, during a year in 1947-1948 he implemented the requirements for a bachelor degree programme at Ohio Kenyon College in the USA (Lennon, 2016). Later on he travelled as one of the leaders of the European Student League in East Asia and the USA for several months, and he was shocked at the social injustice and racial inequality of these countries. It was precisely these trips that revealed to Olof the negative consequences of capitalism and imperialism to societies, therefore, these experiences had effect on his views that was formed at the time (Bondeson, 2013: 1). Then he returned back to Sweden. In 1948 Olof Palme participated in the resistance during the coup d'etat of the communist party in Czechoslovakia, as he married a Czech girl to enable her to move to Sweden. Then they divorced. Palme got his master's degree in 1951 at Stockholm University. He got interested in political activities, and in the politics of Swedish style he saw an progressive alternative both for Soviet socialism and American capitalism (The New York Times, 26/02/2016).

Olof Palme started his political career in 1953, when the prime minister of Sweden Tage Erlander appointed Palme from the Social Democratic Labor Party to be his secretary (About Olof Palme, Olof Palme International Centre, updated 2016). Palme also got familiar with the Swedish political life from within. It is stated that during one of the discussions at the party headquarters in Stockholm Olof Palme introduced a motto of "a strong society". It meant a society which in pursuing social and economic changes, is marked with a extensive collective responsibility and ensures that no group of the society is left aside (Andersson, 2006: 29). Hence in 1957 Olof Palme was elected a member of parliament. In 1956 he married Lisbet and had three children with her. On the day he died his three children were as young as 27, 24 and 17 (Pantti, 2005: 363). In 1963 Palme was promoted by Erlander to the minister without portfolio, and from 1965-1967 he was working as a minister of communications. Olof Palme had strong ideological views, for example, as a minister of education he included learning on Marxism into school curricula, reduced the mark of admission to universities of students so that as many young people as possible pursue higher education. On the issues of foreign policy Palme emphasized the importance to preserve international law and reinforce it and increase the defence of the interests of the smaller states. It should be noted that the idea related to the right of the smaller countries to resist the influence of great powers is considered to be "the Palme doctrine". Hence Palme never avoided criticizing the great superpowers - both the USA and the USSR (Ekengren, 2011: 124; Bondeson, 2013: 2; Agius, 2006: 28). It should be emphasized that in 1968 Olof Palme together with the ambassador of Northern Vietnam in Sweden participated in a demonstration against the involvement of the USA into the war in Vietnam, and he compared the subsequent bombing of Hanoi with bombing of Guernica by the Nazi Germany during the civil war of Spain. Olof Palme was a harsh critic of apartheid in South Africa (Pantti, 2005: 363). Palme not only criticized the US military actions in Vietnam but he also invited and accepted a number of deserters of the US army. He also agitated Norway and Denmark to leave NATO (Jenkins, 1989: 18). As a result, the relations of Sweden and the US deteriorated significantly, when the US President Nixon did not accept the Swedish ambassador to the US and recalled the American ambassador from Sweden. Yet it is essential to understand that Palme never was "anti-American". With regard to the US Palme (Palme, 1970: 579) emphasized that despite the criticism towards the politics of the US his personal views related to the needs of independence of the smaller countries, Sweden and the US have had a long lasting and sincerely friendly relations.

It should be noted that in 1968 Olof Palme heavily criticized the intervention of the USSR into Czechoslovakia (Stockholm News, 25/04/2016). It is also important that Palme supported the activities of the African National Congress and Palestine Liberation Organization, and during the last years of his life he served as a mediator between the conflicting Iran and Iraq states (Lillbacka, 2010: 120). In 1969, on retirement of Erlander, Olof Palme overtook the post of the head of the Social Democrat Labor Party and 
consequently as that of the prime minister of Sweden (Lennon, 2016). This stage was the start of significant changes, which were first of all related to communication between the government and media structures. Palme focused on informal communication with the mass media. It was during his term of office that the first modern press conferences were first held in Sweden, when the representatives of the mass media, at the initiative of the Prime Minister, were invited in order to inform the society about a concrete political issue and possible solutions to it (Larsson, 2012: 267-268).

Olof Palme's peace keeping initiatives and other foreign policy in support of injured during the natural and political disasters, aggression, war during the mediation between the North and the South, West and East and promoting their dialogue are well known. For example, in 1970 Sweden was the global leader according to the support for the developing countries and precisely in this year it implemented its objective to donate one percent from its gross national income for providing support to foreign countries (Ekengren, 2011: 125).

As it was mentioned, Sweden was an integral part of the concept of "active neutrality". It is interesting that active neutrality did not mean Sweden's isolation, and Palme (1970: 579) stated that despite its neutrality in foreign policy, Sweden was a member of the United Nations, exported more than 50 percent of its industrial production, and the scale of immigration into the country was constantly increasing and the mass media provided the citizens of Sweden the necessary information from the entire world. On the other hand, when the Olof Palme's Sweden started criticizing Israel's policy towards Palestinians, some authors state that the seeming neutrality of Sweden is highly selective and this country pursues not only human, but also economic interests. It was deemed that by maintaining Palestinians, the Swedes are aiming at reinforcing their relationships with other rich Arab countries to increase transnational trade volumes (Yegar, Shumacher, 2010: 38).

However, the activity of Palme in creating a welfare state in Sweden was not less significant. According to Palme, the type of the Swedish society, which was oriented towards reaching greater equality was the ideal of the state which was essentially different from the Soviet communism and such a model of liberal society, which was represented by the US. In 1977 Palme expressed a public wish to replace the individualistic system of capitalism by economic democracy (Tsarouhas, 2008: 79). On the other hand, as a severe critic of traditional ideologies, he also did not manage to avoid scandals. According to historic sources, in 1985 Olof Palme was even accused of tax evasion. Harvard University granted free education to Palme's son in return for the lectures read by Olof Palme, and he, most probably by mistake, failed to inform the tax inspectorate thereof (Lindberg, 2013: 98). Despite these events, Palme continued his activities successfully.

Olof Palme formed a true friendship with the leaders of Social Democrats' parties of other Western European countries - with Bruno Kreisky in Austria and Willy Brandt in Germany (Svenska Dagbladet, 27/02/2016). However, Olof Palme's activity in creating a welfare state in Sweden was not less important. For an ideal state the achievements of the public sector were important, which would stabilize the contradictions naturally raised by capitalism. Even though Olof Palme admired Marxism in his youth years, yet his position with regard to public administration in the "democratic socialism" system differed from the Marxist understanding, since Palme saw public administration as an ally of the employees with regard to employers, which was supposed to curb capital attacks rather than "an enemy", for which it would have been important to use the employees for capital interests. Marx saw public sector employers as tools of capitalism in employing and using the employees, and Palme saw in public administration and public sector the subject aiming at social justice that could "improve" and "humanize" the capitalist system and mitigate its contradictions. Public sector, according to such understanding, as well as private sector, contributed to the creation of gross domestic product. However, his strength, as compared to the private sector, was that he guaranteed to the employed the opportunities of strong public social protection, education and cultural fostering. The objective of such a welfare society was to reduce social injustice so that "the rich do not become richer" and "the poor do not become poorer". In Palme's view, fairer distribution was a tool of "democratic socialism", as an ultimate purpose. In this regard, his ideological credo did not differ from the historical one, a credo of social democratic theorist Eduard Bernstein coined a hundred years ago, stating that "The final goal of socialism was nothing; progress towards that goal was everything". "The Swedish functional socialism" is considered 
to be such a variety of capitalism which has got closest to the Western "democratic socialism" ideal, and it was precisely during the period of Palme's governments that the development of this "Swedish model" reached its apogee. Of all the countries in the world, Sweden was the most successful in combining economic effectiveness and social justice, balance between work and capital on the left side of the political spectrum (Okun, 1975). Subsequent periods of social democratic governance were marked with greater compromises and capital interests and marked the retreat of social democracy to the political positions of "centre", where they were did not differ from the conservative-moderates and liberals.

\section{The Importance of Sweden's Social Democrats and Palme's Positions for the Creation of a "Welfare State"}

The Swedish social democratic movement is a social democratic movement that has the greatest achievements in the world, which expanded the limits of this movement and showed what social democrats can and cannot do. For the greater part of the recent century the Swedish Social Democratic Party was the ruling or coalition party in the country. Its greatest achievements were in the area of public sector governance, and mostly in the area of social protection, where poverty was largely eliminated and the middle class was reinforced. The successful creative decades of this country started in 1932 with the Social Democrats coming to power, it lasted even during World War II, when Per Albin Hansson was creating the Folkhemmet ("the People's Home") (Wigh, visited 24/04/2016), and the first three decades after the war, which led to its "golden age", were especially successful. During this period Sweden was constantly progressing in a positive direction, life quality and export were significantly increasing. Sweden was exporting steal, dynamite, paper, machines and telephones. Successful global level corporations such as Volvo, Ericsson, Alfa Laval, etc. were successfully operating in Sweden. Therefore, successfully growing economy and gradual increase of taxes allowed creating an incredible health and social service system, to reinforce domestic policy and actively participate in the implementation of foreign policy (Bondeson, 2013: 1; Bolang, 1983: 38). For example, in domestic policy Palme expressed support for trade unions in a campaign to divert corporate profits into "wage-earners" funds in order to expand social ownership of companies. On the other hand, it is deemed that it is precisely high taxes that became the underlying reason why social democrats lost power in 1976 (Jenkins, 1987: 18; Tilton, 1991: 261).

Certainly, Olof Palme was one of the most prominent figures of the political world not only among social democrats but in the political world in general. He was the prime minister of Sweden in 1968-1976 and in 1982-1986. Palme's views greatly influenced the preceding Prime Minister Tage Erlander (Ruin, 1991). Even though in many regards their views coincided, Olof Palme was to implement his policy at the time when Sweden was not considered to be "an economic miracle" since its development rate slowed down, however, in the social area Sweden continued to be well known for its achievements, which some other countries were trying to copy, however, only the remaining Nordic countries succeeded in doing this. However, even under difficult circumstances Olof Palme never renounced his positions. Andersson (2006: 106), having put the data of historians into a system, draws attention to the famous speech given by Palme in Congress in 1981, which was dedicated to the employees working in the metal industry, in which he stated that "Swedish employers may be likened to the Chilean junta, and neo-liberalism ideology may be described as a happy marriage between military dictatorship and the free market". In it Palme clearly maintained the position that Sweden will never become a country like that of Friedman or Pinochet in Chile, or that of Thatcher in the United Kingdom.

Sweden's social democrats have a unique understanding of the "democratic socialism". That is "functional socialization" ("functional socialism") and "socialization via funds" ("funds socialism"), having in mind which one can state that the activity of social democrats is of "socialist" nature and it contradicts, dissociates itself from liberal capitalism (Adler-Karlsson, 1968: 21; Meidner, 1978). Olof Palme was not afraid to be called "a socialist", but precisely this should be associated with the name of "democratic 
socialism". According to this theory and practice, "functional socialization" curbs separate functions of capitalism, and due to "socialization via funds" ordinary employees are granted rights to participate in capital management. Despite this, these forms of socialization do not replace private ownership as such, capitalist relations are not eliminated and political democracy remains and is reinforced. Liberalism in such a society acquires features of social liberalism, and some people refer to it as merely "Swedish socialism", where private ownership and capitalist relations are directed towards achieving social justice and welfare of the citizens, and the lower levels of the residents are lifted to the middle class, and the middle class is reinforced. Later on Esping-Andersen (Esping-Andersen, 1990) referred to such a state created by social democrats a universal institutional redistributory "universal welfare state", where the expression of marginal individualism is avoided and there are attempts to combine the economically, socially and culturally progressive individualistic interest with the public one, individual interest with the common public interest. The objective of the theoretic and practical activity of social democrats is to avoid potentially contradicting sides' social conflicts and achieve some kind of social balance - social peace (Guogis, 2012: 65), which was to be achieved by the means of "integrative democracy" (Tilton, 1991: 257). Other social criteria of socialism are also very important - that is universal social policy, full employment, etc., which emphasize and reinforce the positions of the Swedish Social Democrats Labor Party - as a "leftist party" - in the political spectrum among other political parties.

During the term of office of Palme as prime minister, public sector in Sweden was largely expanded. In this regard, Palme continued the work started by Erlander. Palme provided the following reasons for the necessity of theoretically and practically strong public sector:

(1) An ideological cause: regulatory state (by expanding the opportunities of education, by improving state health and social protection, by improving employment opportunities, etc.) creates the conditions for human freedom. However, this is not unbridled freedom of liberal type, and not a communist freedom "suppressed" by totalitarianism.

(2) The social-economic cause: increased material welfare does not reduce, but on the contrary increases the need for education, scientific research, health and social protection, construction of good roads, however, simultaneously welfare creates such obstacles that are too difficult for individuals to overcome (Palme, 1984: 8). Collective actions are necessary, which the citizens desire and encourage.

(3) The cause of aiming at social peace: an extensive public sector, the expenditures of which made 67 percent of the gross domestic product, together with trade unions (members of which were 85 percent of all the employed in Sweden), according to Palme, were the forces which had to "counterbalance" the industrial forces that are in private hands (95 percent of industry in Sweden was privately owned) (Palme, 1984: 9). Palme based his entire social and economic policy on the balance of these three powers. Having in mind that the members of trade unions were admitted into the Social Democrats Party collectively, the entire society was interested in the public sector, and the Social Democrats Party ensured a social basis for a long time, both in terms of the support of the members of the party and of the part of the society supporting the Swedish Social Democrats Labor Party during the election (Guogis, 2000: 54).

On the other hand, in the programme of 1982, one of the objectives was protection of citizens from bureaucracy. The main ambition of Olof Palme was to create public services that would be oriented towards civic participation. To this end, he established a new Public Sector Ministry, the task of which was to implement the reforms of the public sector institutions (Naschold, 1996: 104).

Palme's arguments regarding the advantage of Swedish type of a country against a US type of country were convincing (the latter was increasingly favourably seen by the Swedish conservatives (moderates) and liberals). It is obvious that both types of the countries were Western "welfare states". However, in Palme's views, the conservatives and the liberals discredited the very idea of "a welfare state". First of all, by essentially pursuing only economic effectiveness, they depersonalized the society and left to 
function only "the naked economic powers", and a number of problems accumulated as a result of this, for example, unemployment became widespread (Palme, 1984: 8, 13). In this way, the conservatives and the liberals did not submit the unemployed to the destiny. They allocated them unemployment benefits, but the support of conservatives and liberals came to an end. This kind of caring of the weakest ones, according to Palme, was a selective social policy, which clearly divided the society into (1) those who were paying taxes to support "the unnecessary" members of the society and (2) those who were receiving benefits so that they can make both ends meet. In this case, the former ones, by paying taxes, did not benefit from this themselves and were always against tax increase. The latter ones were also unsatisfied since they did not have a job. Palme supported a different model - that of "social programmes for all", "social policy for all" (Guogis, 2000: 54). The underlying principle of it was: (1) that everybody who could was working; (2) all the employed were paying rather high taxes - in this way social programmes were financed; (3) everybody was greatly benefiting from social programmes since they were a of a universal nature rather than selective. This kind of institutional type policy increased the number of unsatisfied people since a number of people were feeling unsatisfied. Only the citizens with highest income were unsatisfied since they were mostly taxed. Palme was trying to convince that only the society acting on the basis of these principles had a future and only a state based on these principles may be considered to be a real "state of universal welfare". It should be noted that the economic processes that were encouraged by globalization during the years of Palme's rule was not that much advanced to talk like now, 30 years after his death, about the problems of creation of "a welfare society" rather than "a welfare state", which are not the same. The Swedish welfare state, even though it accepted a number of political immigrants and integrated them in 1970s and 1980s, it was still considered to be a national welfare state, which was not yet characteristic of subsequent "deconstruction" of the state by globalization, and state regulation bore its fruit. In addition to this, with the conservatives and liberals coming into power in Sweden in 1976 and staying there until 1982, the economic situation of the country deteriorated - the period of their governance coincided with the first economic crisis after the war (Guogis, 2000: 53). 1982 was again a successful year to the Swedish Social Democrats Labor Party led by Palme - it returned to power for 9 years, however, with Palme's governance it remained there for only half of that time; after Palme's death the leadership of the party was overtaken by Ingvar Carlsson (Ruin, 1991).

The life of the unique Swedish politician Palme ended by a tragedy. The world lost Olof Palme on 28 February 1986. Even the last minute of his life he gave interview to the correspondent of a local newspaper and talked about the necessity of nuclear disarmament and political debate, in this way trying to ensure peace and implement the vision of a safer world (Maylam, 2011: 209). Later on, Palme and his wife prepared to go to the cinema, to which Olof Palme went without bodyguard protection, and after the film was shot to his back (Bondeson, 2013: 9-13). Taking into consideration the fact that he was controversial but a simple politician and a person of the people rather than of the elite, there are doubts as to whether the assassination was a coincidence. Therefore, the assassination of the Swedish Prime Minister remains to be a complex issue and an object of the creators of conspiracy theories (Lillbacka, 2010: 119). On the other hand, his assassination shocked not only the Swedish community but also the international community since Olof Palme was not only a prominent personality but also a symbol of a welfare state and a social democratic system, whose speeches on equality and freedom in the world were a symbol of the model of an ideal society (Pantti, 2005: 363-365). After Palme's death in 1987 The Olof Palme Foundation for International Understanding and Universal Security was established in his honour, which would allocate scholarships to talented youth aiming at analyzing the problems of peace and disarmament (Maylam, 2011: 211).

Olof Palme, who served not only to the idea of "social democracy" of his country but also to the global community, welfare and peace, will remain in the memory of all the people who knew him either directly or indirectly, as a person of his age and a role model to future generations. 


\section{Conclusions}

The chairman of the Swedish Social Democratic Party and Prime Minister Olof Palme represent the doctrine of "democratic functional socialism" both on the theoretic-ideological and practical levels, both in foreign and domestic policy.

During the years of Olof Palme's governance the so-called "Swedish model" was fully revealed, which was characteristic of "social peace" - some kind of balance and compromise between the government, the employees and employers supported by "integrative democracy".

"Swedish socialism" was characteristic of mitigation of the contradictions of capitalism and private property, which allowed talking about the human nature of such a system, compromise between work and capital on the left side of the political spectrum.

During the years of governance of Olof Palme the public sector of Sweden expanded and public administration was reinforced. Palme saw the public and public administration as an ally of employees in the pursuit of social justice and economic effectiveness.

During the period of governance of Olof Palme not only in domestic but also in foreign policy of Sweden exceptional achievements were made in supporting developing and smaller countries, criticizing and condemning various aggressions and wars in mediating in the global policy between the North and the South and the West and the East.

Personal convictions of Olof Palme were in line with his factual life even on the day of his assassination - on 28 February 1986, when he, walking from the cinemas in the centre of Stockholm without personal protection, was shot by a bullet of an unknown assassin. This year we are commemorating the $30^{\text {th }}$ tragic anniversary since we lost Olof Palme.

\section{References}

About Olof Palme. (2016). Olof Palme International Center. Available at: http://www.palmecenter.se/en/about-olofpalme/ [visited 2016.04.24].

Adler-Karlsson, G. (1968). Functional Socialism. A Swedish Theory for Democratic Socialization. Uppsala.

Agius, C. (2006). New Approaches to Conflict Analysis: Social Construction of Swedish Neutrality: Challenges to Swedish Identity and Sovereignty. Manchester: Manchester University Press.

Andersson, J. (2006). Critical Labour Movement Studies: Between Growth and Security: Swedish Social Democracy from a Strong Society to a Third Way. Manchester: Manchester University Press.

Bolang, C. (1983 winter). Letter from Stockholm: Sweden's lurch to the left. Mckinsey Quarterly [serial online], Vol. (4), p. 37-44.

Bondeson, J. (2013). Blood on the Snow: The Killing of Olof Palme. Ithaca: Cornell University Press.

Crouch, D. (2016). Questions Nag in Sweden 30 years After Leader's Assassination. The New York Times, 2016.02.26 [visited 2016.04.25].

Ekengren, A. M. (2011). How Ideas Influence Decision-Making: Olof Palme and Swedish foreign policy, 1965-1975. Scandinavian Journal of History, Vol. 36 (2), p. 117-134.

Esping-Andersen, G. (1990). The Three Worlds of Welfare Capitalism. Princeton. New Jersey: Princeton University Press.

Guogis, A. (2000). Švedijos socialdemokratu ideologija 1932-1994 metais. Vilnius: Eugrimas.

Guogis, A. (2012). Kai kurie Švedijos socialdemokratijos ideologiniai aspektai socialiniu požiūriu. Socialinis darbas, Vol. 11(1), p. 59-72.

Jenkins, P. (1989). The assasination of Olof Palme: evidence and ideology. Contemporary Crises, Vol. 13, p. 15-33.

Larsson, L. (2012). From yearly to daily press meetings: The development of the government press relations in Sweden. Public Relations Inquiry, Vol. 1(3), p. 257-283.

Lennon, T. (2016). Murder of the Swedish Prime Minister Olof Palme - the man who kicked the hornet's nest - still unsolved after 30 years. The Daily Telegraph, 2016.03.25 Available at: http://www.dailytelegraph.com.au/news/ murder-of-the-swedish-prime-minister-who-kicked-the-hornets-next-still-unsolved-after-30-years/news-story/33 97d20a1b1dac2b37d0be9e799ac29b [visited 2016.04.24]. 
Lillbacka, R. (2010). Was Olof Palme Killed by an Intelligence Agency? International Journal of Intelligence and Counter Intelligence, Vol. 24 (1), p. 119-147.

Lindberg, H. (2013). Knowledge and Policy Change. Newcastle upon Tyne: Cambridge Scholars Publishing.

Maylam, P. (2011). Enlightened Rule: Portraits of Six Exceptional Twentieth-Century Premiers. Bruxelles: Peter Lang AG.

Meidner, R. (1978). Employee Investment Funds. London: George Allen and Unwin.

Naschold, F. (1996). Public Sector Transformation: Rethinking Markets and Hierarchies in Government. Amsterdam: John Benjamins Publishing Company.

Okun, A. M. (1975). Equality and Efficiency: The Big Tradeoff. Washington: The Brookings Institution.

Olof Palme - en symbol for socialdemokraternas storhetstid. (2016). Svenska Dagbladet, 2016.02.27.

Palme, O. (1984). Employment and Welfare. The 1984 Jerry Wurf Memorial Lecture. Harvard Law School.

Palme, O. (1970). Sweden. Vital Speeches of the day [serial online]. July 15, Vol. 36(19), p. 578.

Pantti, M. (2005 august). Masculine tears, feminine tears - and crocodile tears: Mourning Olof Palme and Anna Lindh in Finnish newspapers. Journalism, Vol. 6(3), p. 357-377.

Ruin, O. (1991) Three Swedish Prime Ministers: Tage Erlander, Olof Palme and Ingvar Carlsson. West European Politics (Special Issue: Understanding the Swedish Model), Vol. 14, Issue 3, p. 58-82.

Tilton, T. (1991). The Political Theory of Swedish Socialdemocracy. Oxford: Oxford University Press.

Tsarouhas, D. (2008). Social Democracy in Sweden: The Threat from a Globalised World. London: I. B. Tauris.

Yegar, M., Shumacher, Y. (2010). An End to the Swedish Game? Israel Journal of Foreign Affairs, Vol. 4 (1), p. 37-42.

Who was Olof Palme? (2016). Stockholm News, 2016.04.25. Available at: http://www.stockholmnews.com/more. aspx?NID $=6826$

Wigh, S. (2016). Det svenska folkhemmet. Available at: https://diamanten.wikispaces.com/file/view/ Det + svenska+folkhemmet.pdf (visited 2016.04.24).

1986: Swedish prime minister assassinated. Available at: http://news.bbc.co.uk/onthisday/hi/dates/stories/february/28/ newsid_2802000/2802181.stm [visited 2016.04.24].

\title{
OLOFO PALMĖS VIEŠ OJO VALDYMO TOBULINIMAS IR ISTORINIS IDEJINIS PALIKIMAS (PRAËUUS 30 METU NUO JO NUŽUDYMO STOKHOLME)
}

\author{
Arvydas Guogis, Adomas Vincas RaKšnys \\ Mykolo Romerio universitetas (Lietuva)
}

\section{Santrauka}

Olofas Palmė yra ne tik Švedijos socialdemokratų partijos geriausių valdymo metų simbolis, bet ir ryškiausiai matoma figūra tarptautiniame darbo bei taikos judejjime antrojoje XX amžiaus pusèje. Savo veikla O. Palmè parodè socialdemokratijos ribas, ką gali ir ko negali socialdemokratai palankiausiai jų valdymui susiklostančiomis aplinkybėmis. O. Palmè daug dėmesio skyrė efektyviam viešajam valdymui, kuris turẻjo sušvelninti kapitalizmo prieštaravimus ir suteikti jam ,žmogišką“ pavidalą. Vidaus politikoje jis buvo aktyvus „demokratinio funkcinio socializmo“, dažnai pavadinamo tiesiog „švedišku modeliu“, kūrejjas. „Demokratinị socializmą" kuriant gerovès valstybę O. Palmè suprato ir kaip vystymosi priemonę, ir kaip galutinị tikslą. Užsienio politikoje jis aktyviai palaikė taikos tarp Šiaurès ir Pietų, Vakarų ir Rytų šalių užtikrinimo ir vystymosi skatinimo iniciatyvas. Valdant O. Palmei Švedijoje buvo santykinai gerai, t. y. socialinès taikos būdu, išspręsta ekonominio efektyvumo ir socialinio teisingumo darnos problema. Jam valdant šioje Šiaurès šalyje ypač išsiplète ir sustiprejo viešasis sektorius bei viešasis administravimas, i 
kuriuos O. Palmė žiūrèjo kaip į dirbančiųų sajungininkus, derinant pozicijas su darbdaviais. Jis pasižymėjo ir kaip aršus neoliberalizmo idejjų kritikas, žmogaus teisių bei laisvių, mažujų valstybių neutraliteto gynejjas, branduolinio nusiginklavimo politikos šalininkas.

Šiemet minime 30 metų nuo tos tragiškos dienos, kai 1986 m. vasario 28 d. O. Palmè, grįždamas iš kino filmo peržiūros su žmona Lisbet be apsaugos, nušautas nenustatyto užpuoliko pačiame Stokholmo centre. Tą nelemtą dieną, prieš 30 metų, Švedija ir pasaulis neteko didžios asmenybės ir įkvepiančio pavyzdžio ateities kartoms.

PAGRINDINIAI ŽODŽIAI: Olofas Palmè, Švedija, socialdemokratija, demokratinis socializmas, funkcinis socializmas, gerovès valstybè, viešasis valdymas, taika.

JEL KLASIFIKACIJA: B 14, L 30. 